\title{
Feeding ecology of elasmobranch fishes in coastal waters of the Colombian Eastern Tropical Pacific
} Andrés F Navia*1,2, Paola A Mejía-Falla1,2 and Alan Giraldo ${ }^{2}$

\author{
Address: ${ }^{1}$ Fundación Colombiana para la Investigación y Conservación de los Tiburones y Rayas, SQUALUS. Carrera 64 A No 11A-53, Cali, \\ Colombia, USA and ${ }^{2}$ Grupo de Investigación en Ecología Animal, Sección de Zoología, Departamento de Biología, Universidad del Valle. A.A. \\ 25360, Cali, Colombia, USA \\ Email: Andrés F Navia* - anavia@squalus.org; Paola A Mejía-Falla - pmejia@squalus.org; Alan Giraldo - ecologia@univalle.edu.co \\ * Corresponding author
}

Published: 18 September 2007

BMC Ecology 2007, 7:8 doi:10.1 186/1472-6785-7-8
Received: 13 January 2007

Accepted: 18 September 2007

This article is available from: http://www.biomedcentral.com//472-6785/7/8

(C) 2007 Navia et al; licensee BioMed Central Ltd.

This is an Open Access article distributed under the terms of the Creative Commons Attribution License (http://creativecommons.org/licenses/by/2.0), which permits unrestricted use, distribution, and reproduction in any medium, provided the original work is properly cited.

\begin{abstract}
Background: Stomach contents of I $3 \mid$ specimens of five elasmobranch species (Mustelus lunulatus, Dasyatis longa, Rhinobatos leucorhynchus, Raja velezi and Zapteryx xyster) caught in the central fishing zone in the Pacific Ocean of Colombia were counted and weighed to describe feeding habits and dietary overlaps.

Results: Twenty-one prey items belonging to four major groups (stomatopods, decapods, mollusks and fish) were identified. Decapod crustaceans were the most abundant prey found in stomachs. The mantis shrimp Squilla panamensis was the main prey item in the diet of M. lunulatus; tiger shrimp Trachypenaeus sp. was the main prey item in the diet of Rhinobatos leucorhynchus and Raja velezi, and Penaeidae shrimp were the main prey items in the diet of $Z$. xyster. Furthermore, fish were important in the diet of Raja velezi, $Z$. xyster and $D$. longa. The greatest diet breadth corresponded to Z. xyster whereas M. lunulatus was the most specialized predator. Finally, four significant diet overlaps between the five species were found, attributable mainly to Squillidae, Penaeidae and Fish.

Conclusion: Shrimps (Penaeidae and stomatopods) and benthic fishes were the most important food types in the diet of the elasmobranch species studied. Diet breadth and overlap were relatively low. Determination of food resource partitioning among the batoid species studied was not possible. However, we identified partitions in other niche axes (time of feeding activity and habitat utilization). It is possible to assume that diffuse competition could be exceeding the biunivocal competition among the studied species. Therefore, this assemblage would have a strong tendency to trophic guild formation.
\end{abstract}

\section{Background}

Elasmobranch fishes are among the top predators in the marine environment and thus play an important role in marine ecosystems, potentially regulating, through predation, the size and dynamics of their prey populations [1]. An understanding of competitive and predatory processes is thus necessary to gain insight into the role of predators in influencing niche, community and food web structure, and ultimately ecosystem dynamics [2]. In this sense, the theory about resource partitioning is frequently attributed to competitive or cooperative interactions. This approximation predicts that spatial or temporal partitioning may 
increase the tolerance of niche overlap, and may reduce the pressure of competition among coexisting species $[3,4]$.

Several studies have evaluated the influence of resource partitioning in teleost fishes to explain reduction in competition potential [5-7]. These authors reported a positive relationship between habitat partitioning and the magnitude of diet overlap or competitive interactions, when the interacting species had the same diet preferences. Furthermore, Ross [8] found that the first resource that is fractioned is food, followed by habitat. Despite the ecological importance of elasmobranch fishes for the marine ecosystem, resource partitioning and competitive exclusions in this taxonomic group are poorly understood.

A substantial amount of data on the diet of different elasmobranch species has been reported to date. Elasmobranch fishes are often typified as opportunistic predators, with a wide trophic spectrum that includes plankton to marine mammals. In general, oceanic elasmobranch species feed on squid and big fishes $[9,10]$, whereas the coastal and benthic species feed on crustaceans, mollusks and small or juvenile fishes [11-13]. A few species feed on other elasmobranchs, birds, reptiles or marine mammals $[14,15]$. Ontogenetic variation in diet is well known $[16,17]$, with a strong tendency to ingest larger and more mobile animals with increasing size.

Research on trophic relationships among sympatric species of elasmobranchs is scarce and results vary among studies [18-20]. Varying overlap values between coexisting species, successive sizes of a same species, or even between sexes have been reported. Moreover, the effect of habitat and feeding time on the diet of sympatric species is very poorly known [21-23]. In the Eastern Pacific Ocean of Colombia (EPOC) the study of elasmobranch diet is in its infancy [24-26]. The existing studies have only considered three of 87 elasmobranch species reported for the area [27]. Furthermore, no research has addressed trophic interactions among sympatric fish species in coastal or oceanic environments.
Therefore, the object of this study was to quantify and compare the diet and trophic interactions of coastal elasmobranch species from the Eastern Tropical Pacific of Colombia, and to suggest possible mechanisms for their coexistence.

\section{Results \\ Feeding activity}

A total of 131 specimens of five species (Mustelus lunulatus, Dasyatis longa, Rhinobatos leucorhynchus, Raja velezi and Zapteryx xyster) were analyzed. All specimens were captured in shallow waters (between 15 and $60 \mathrm{~m}$ depth). Significant differences in the bathymetric distribution of the species were found $(\mathrm{KW}-\mathrm{H}(4,162)=105.16$, p $<<$ 0.0001 ), with Zapteryx xyster and Raja velezi found in narrower depth ranges and under 35 and $40 \mathrm{~m}$, respectively. Dasyatis longa and Rhinobatos leucorhynchus were associated with the shallowest depths (Figure 1). Mustelus lunulatus, D. longa and Rhinobatos leucorhynchus were captured mainly during diurnal bottom trawling, while Z. xyster were captured mainly during nocturnal bottom trawling. Raja velezi was captured only at night. Only R. leucorhynchus and $Z$. xyster showed significant differences in hourly feeding activity (Table 1). We did not carry out analyses of ontogenetic shifts in diet because we did not capture individuals from all sizes intervals.

\section{Diet composition}

The proportion of empty stomachs varied widely among species, with a minimum vacuity index of $9.5 \%$ in $M$. lunulatus and a maximum vacuity index of $47.6 \%$ in $D$. longa (Table 2). The main prey item of Mustelus lunulatus were stomatopods from the family Squillidae $(\% \mathrm{~N}=$ $73.2 \%, \% \mathrm{~W}=36.1 \%$, and occurrence $78.6 \%)$ (Table 3$)$, with Squilla panamesis being the main prey item (92.8 $\%$ IRI). An additional twelve prey categories were identified in the stomachs of M. lunulatus, which feed opportunistically on shrimps, crabs and gasteropods in low percentages.

In D. longa stomatopods were the most frequent prey item $(14.3 \%)$ and had the highest percent by number (58.3\%),

Table I: Sampling data of elasmobranchs caugth

\begin{tabular}{|c|c|c|c|c|c|c|}
\hline \multirow[b]{2}{*}{ Species } & \multirow[b]{2}{*}{$\mathrm{n}$} & \multicolumn{2}{|c|}{ Capture (n) } & \multirow[b]{2}{*}{$P$} & \multicolumn{2}{|c|}{ Size $(\mathrm{cm})$} \\
\hline & & Diurnal & Nocturnal & & Min & Max \\
\hline Mustelus lunulatus & 42 & 15 & 16 & 0.8202 & 55 & 125 \\
\hline Dasyatis longa & 21 & 19 & 5 & 0.8906 & 106 & 210 \\
\hline Rhinobatos leucorhynchus & 24 & 10 & 18 & 0.0017 & 37 & 67 \\
\hline Raja velezi & 13 & 0 & 15 & - & 48 & 80 \\
\hline Zapteryx xyster & 31 & 3 & 51 & 0.0353 & 27 & 66 \\
\hline
\end{tabular}

Sampling data of elasmobranchs caugth in the Eastern Tropical Pacific Ocean of Colombia and range size of these species. $n$ : number of individuals captured. $p$ : $p$-value of $K-W$ test. 


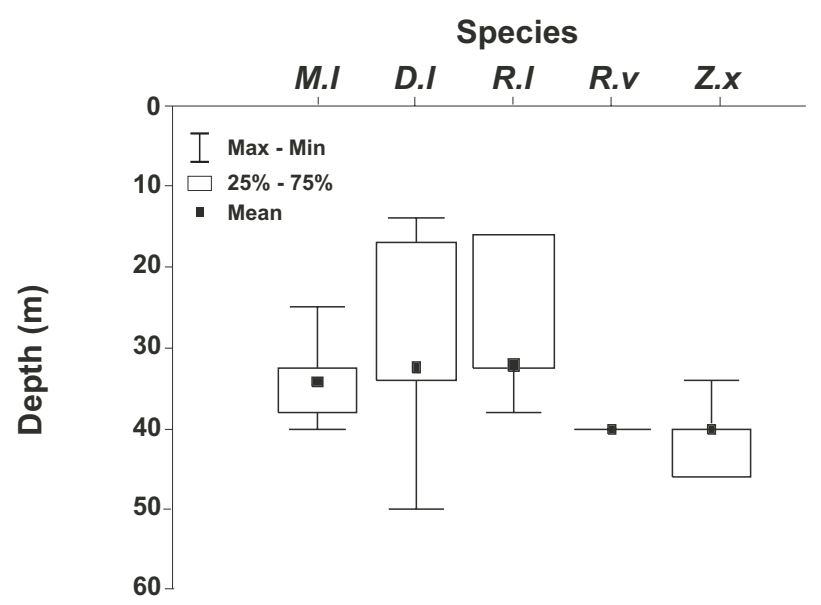

Figure I

Bathymetric distribution of the elasmobranch species studied. (M.I) is Mustelus lunulatus, (D.I) is Dasyatis longa, (R.I) is Rhynobatos leucorhynchus, (R.v) is Raja velezi and (Z.x) is Zapteryx xyster.

whereas fishes had the highest percent by weight $(36.8 \%)$ (Table 3). Digested material was 35.1\% and vacuity index was $47.6 \%$. The main prey items were Squillidae $(54.9 \%$ \%IRI) and fishes (31.1\%IRI). The diet of this species also included decapods and gastropods.

In Rhinobatos leucorhynchus the most frequent (66.6\%), abundant $(85.6 \%)$ and with highest percent by weight $(41.7 \%)$ prey item was decapods, following by fishes $(12.5,11.4$ and $30.9 \%$ respectively) (Table 3$)$. The main prey item was Trachypenaeus sp. (60.4\%IRI). However, stomatopods and crabs (Portunidae) were also found in the diet of this species. The vacuity index was low (20. $8 \%)$.

Only two prey items were identified in $R$. velezi, fishes and decapods. Fishes were the most frequent item (53.8\%), and also the most abundant by number (53.9\%) and weight (50.8\%), and collectively (70.4\% IRI). Among the fishes, only Batrachoididae could be identified (Table 3 ).

Six prey categories were identified in stomach contents of Z. xyster (Table 3). Fishes and penaid shrimp occurred most frequently (> 16\%) and were the most abundant by number (27.3\% each), however shrimp were the most abundant by weight (31.4\%). For this species decapods were the most important prey item with $43.2 \%$ IRI.

\section{Diet breadth and overlap}

Use of a three-dimensional graphical representation of the diet [28] facilitated the description of feeding styles of the five species studied (Figure 2). The diet of M. lunulatus was specialized, with most individuals consuming Squilla panamensis, although this species also feed on twelve other prey items. In contrast, the diet of $Z$. xyster was more heterogeneous and generalized because fishes, decapods and stomatopods were consumed by the majority of individuals. These results were confirmed by Levin's breadth index, which yielded the greatest diet breadth for Z. xyster, while M. lunulatus was the most specialized predator (Table 4).

Following Zares \& Rand's [29] criteria, four biologically significant diet overlaps were established among the studied species (Table 5). A significantly high overlap was found between $M$. lunulatus and D. longa, which shared shrimps of the family Squillidae. Significant overlaps were also found between Rhinobatos leucorhynchus and Raja velezi, and $R$. leucorhynchus and $Z$. xyster, which shared Penaeidae, and between Raja velezi and Z. xyster which shared fish and Penaeidae. The random overlap hypothesis was rejected ( $\mathrm{p}=0.010)$, suggesting low overlap and low partitioning of resources [30].

\section{Discussion}

The composition of diets suggests that all elasmobranchs studied are species that feed on epibenthic invertebrates (mainly stomatopods and decapods) and fish. This result is highly associated with the source of the samples analyzed, i.e., elasmobranchs captured in bottom trawl fish-

Table 2: Feeding activity of captured elasmobranchs

\begin{tabular}{|c|c|c|c|c|c|c|c|}
\hline Specie & $\mathrm{n}$ & Es & VI & $\chi_{n}$ & $\mathrm{Cl}_{\chi \mathrm{n}}$ & $\chi_{w}$ & $\mathrm{Cl}_{\chi w}$ \\
\hline $\begin{array}{l}\text { Mustelus } \\
\text { lunulatus }\end{array}$ & 42 & 3 & 9.5 & 2.5 & $1.9-3.1$ & 8.9 & $7.8-11$ \\
\hline Dasyatis longa & 21 & 10 & 47.6 & 0.9 & $0.3-1.2$ & I.I & $0.3-1.9$ \\
\hline $\begin{array}{l}\text { Rhinobatos } \\
\text { leucorhynchus }\end{array}$ & 24 & 5 & 20.8 & 1.8 & I.I -2.5 & 1.3 & $0.6-2.0$ \\
\hline Raja velezi & 13 & 4 & 38.8 & 1.0 & $0.3-1.7$ & 6.3 & $0.2-12.4$ \\
\hline Zapteryx xyster & 31 & 11 & 35.5 & 0.9 & $0.5-1.3$ & I.I & $0.6-1.6$ \\
\hline
\end{tabular}

Feeding activity of elasmobranch captured in the Eastern Tropical Pacific Ocean of Colombia. Number of stomachs analyzed (n), Empty stomachs $(E s)$, Vacuity Index $(V I)$, mean number of prey per stomach $\left(x_{n}\right)$, $95 \%$ Confidence Interval for $\chi_{n}(C l x n)$, mean weight of prey per stomach $\left(x_{w}\right)$, $95 \%$ Confidence Interval for $\chi_{w}(C l x w)$. 
Table 3: Diet composition of captured elasmobranchs

\begin{tabular}{|c|c|c|c|c|c|c|c|c|c|c|c|c|c|c|c|c|c|c|c|c|}
\hline \multirow{2}{*}{$\infty$} & \multicolumn{4}{|c|}{ M. lunulatus } & \multicolumn{4}{|c|}{ D. longa } & \multicolumn{4}{|c|}{ R. leucorhynchus } & \multicolumn{4}{|c|}{$R$. velezi } & \multicolumn{4}{|c|}{ Z. xyster } \\
\hline & $\% \circ$ & $\% N$ & $\% \mathrm{~W}$ & $\%$ IRI & $\% \circ$ & $\% \mathrm{~N}$ & $\% \mathrm{~W}$ & $\%|R|$ & $\% \circ$ & $\% \mathrm{~N}$ & $\% \mathrm{~W}$ & $\%|R|$ & $\% \circ$ & $\% \mathrm{~N}$ & $\% \mathrm{~W}$ & $\%|R|$ & $\% \circ$ & $\% \mathrm{~N}$ & $\% \mathrm{~W}$ & $\%$ IRI \\
\hline CRUSTACEA & & & & & & & & & & & & & & & & & & & & \\
\hline $\begin{array}{l}\text { STOMATOPO } \\
\text { DA }\end{array}$ & & & & & & & & & & & & & & & & & & & & \\
\hline Squillidae & & & & & 14.28 & 58.30 & 4.48 & 54.87 & 4.16 & 2.85 & 0.31 & 0.31 & & & & & & & & \\
\hline $\begin{array}{l}\text { Squilla } \\
\text { panamensis }\end{array}$ & 61.90 & 62.90 & 28.10 & 92.77 & & & & & & & & & & & & & 12.90 & 18.20 & 26.00 & 20.83 \\
\hline Squilla parva & 14.28 & 9.27 & 5.95 & 4.01 & & & & & & & & & & & & & & & & \\
\hline $\begin{array}{l}\text { Pseudosquilla } \\
\text { similis }\end{array}$ & 2.38 & 1.03 & 2.07 & 0.12 & & & & & & & & & & & & & & & & \\
\hline Total & 78.56 & 73.20 & 36.10 & 96.90 & 14.28 & 58.30 & 4.48 & 54.87 & 4.16 & 2.85 & 0.31 & 0.31 & & & & & 12.90 & 18.20 & 26.00 & 20.83 \\
\hline DECAPODA & & & & & & & & & & & & & & & & & & & & \\
\hline Portunidae & & & & & & & & & 8.33 & 8.57 & 0.47 & 1.79 & & & & & & & & \\
\hline Euphylax sp. & 2.38 & 1.03 & 0.40 & 0.05 & & & & & & & & & & & & & & & & \\
\hline Portunus asper & 4.76 & 3.09 & 7.32 & 0.78 & & & & & & & & & & & & & & & & \\
\hline $\begin{array}{l}\text { Callinectes } \\
\text { toxotes }\end{array}$ & 2.38 & 1.03 & 0.40 & 0.05 & & & & & & & & & & & & & & & & \\
\hline Hepatus sp. & 4.76 & 2.06 & 0.75 & 0.21 & & & & & & & & & & & & & & & & \\
\hline Brachiura & & & & & & & & & & & & & & & & & 3.20 & 4.54 & 0.59 & 0.56 \\
\hline Penaeidae & & & & & & & & & 25.00 & 31.30 & 10.30 & 24.82 & & & & & 19.40 & 27.3 & 31.4 & 41.89 \\
\hline $\begin{array}{l}\text { Pennaeus } \\
\text { occidentales }\end{array}$ & 7.14 & 2.06 & 0.75 & 0.23 & & & & & & & & & & & & & & & & \\
\hline $\begin{array}{l}\text { Trachypenaeus } \\
\text { sp. }\end{array}$ & 4.76 & 2.06 & 0.40 & 0.49 & & & & & 33.30 & 45.70 & 30.30 & 60.44 & $\begin{array}{c}15.3 \\
8\end{array}$ & $\begin{array}{c}46.2 \\
0\end{array}$ & $\begin{array}{c}45.7 \\
0\end{array}$ & 29.57 & & & & \\
\hline Palaemonidae & 2.38 & 9.27 & 4.11 & 0.49 & & & & & & & & & & & & & & & & \\
\hline Hipiddae & 7.14 & 4.12 & 2.20 & 0.71 & 4.76 & 8.33 & 15.70 & 6.98 & & & & & & & & & 3.20 & 4.54 & 2.09 & 0.74 \\
\hline $\begin{array}{l}\text { Total } \\
\text { Decapoda }\end{array}$ & 35.70 & 24.70 & 16.50 & 3.01 & 4.76 & 8.33 & $\begin{array}{c}15.7 \\
0\end{array}$ & 6.98 & $\begin{array}{c}66.6 \\
3\end{array}$ & $\begin{array}{c}85.6 \\
0\end{array}$ & $\begin{array}{c}41.7 \\
0\end{array}$ & $\begin{array}{c}87.0 \\
5\end{array}$ & $\begin{array}{c}15.3 \\
8\end{array}$ & $\begin{array}{c}46.2 \\
0\end{array}$ & $\begin{array}{c}45.7 \\
0\end{array}$ & $\begin{array}{c}29.5 \\
7\end{array}$ & 25.80 & 36.40 & 34.10 & 43.19 \\
\hline MOLLUSCA & & & & & & & & & & & & & & & & & & & & \\
\hline $\begin{array}{l}\text { GASTEROPOD } \\
\text { A }\end{array}$ & & & & & & & & & & & & & & & & & & & & \\
\hline Buccinidae & 2.38 & 1.03 & 0.03 & 0.04 & & & & & & & & & & & & & & & & \\
\hline Agaronia testacea & & & & & 4.76 & 8.33 & 7.62 & 4.59 & & & & & & & & & & & & \\
\hline $\begin{array}{l}\text { Distorsio } \\
\text { decussata }\end{array}$ & & & & & 4.76 & 8.33 & 7.62 & 2.71 & & & & & & & & & & & & \\
\hline BIVALVIA & & & & & & & & & & & & & & & & & & & & \\
\hline Terebridae & 2.38 & 1.03 & 0.16 & 0.04 & & & & & & & & & & & & & & & & \\
\hline $\begin{array}{l}\text { Total } \\
\text { Mollusca }\end{array}$ & 4.76 & 2.06 & 0.19 & 0.08 & 9.52 & 16.70 & 7.92 & 7.30 & & & & & & & & & & & & \\
\hline FISHES & & & & & & & & & & & & & & & & & & & & \\
\hline Fish & & & & & 9.50 & 16.70 & 36.80 & 31.05 & 12.50 & 11.40 & 30.90 & 12.64 & $\begin{array}{c}38.4 \\
6\end{array}$ & $\begin{array}{c}38.5 \\
0\end{array}$ & $\begin{array}{c}37.4 \\
0\end{array}$ & 61.17 & 16.10 & 27.30 & 14.60 & 24.81 \\
\hline Batrachoididae & & & & & & & & & & & & & $\begin{array}{l}15.3 \\
8\end{array}$ & $\begin{array}{c}15.4 \\
0\end{array}$ & $\begin{array}{c}13.4 \\
0\end{array}$ & 9.26 & & & & \\
\hline Cynoglossidae & & & & & & & & & & & & & & & & & 9.70 & 18.20 & 13.70 & 11.16 \\
\hline Total Fishes & & & & & 9.50 & 16.70 & $\begin{array}{c}36.8 \\
0\end{array}$ & 31.05 & $\begin{array}{l}12.5 \\
0\end{array}$ & 11.4 & $\begin{array}{c}30.9 \\
0\end{array}$ & 12.6 & $\begin{array}{c}53.8 \\
4\end{array}$ & $\begin{array}{c}53.9 \\
0\end{array}$ & $\begin{array}{c}50.8 \\
0\end{array}$ & $\underset{3}{70.4}$ & 25.80 & 45.50 & 28.30 & 35.97 \\
\hline $\begin{array}{l}\text { Digested } \\
\text { material }\end{array}$ & & & 47.20 & & & & 35.10 & & & & 27.10 & & & & 3.52 & & & & 11.40 & \\
\hline
\end{tabular}

Prey items observed in stomachs of five species of elasmobranchs captured in the Eastern Tropical Pacific Ocean of Colombia. \%O is frequency of occurrence, \% $\mathrm{N}$ is percentage by number, \%W is percentage by weight 
Table 4: Diet breadth of elasmobranchs caugth

\begin{tabular}{llll}
\hline & & \multicolumn{2}{c}{$\begin{array}{c}\text { Percentage by } \\
\text { number }(\% N)\end{array}$} \\
\hline Species & $N$ & $B_{i}$ & $B_{A}$ \\
\hline Mustelus lunulatus & 13 & 2.40 & 0.12 \\
Dasyatis longa & 5 & 2.57 & 0.39 \\
Rhinobatos leucorhynchus & 5 & 3.05 & 0.51 \\
Raja velezi & 3 & 2.60 & 0.53 \\
Zapteryx xyster & 6 & 4.57 & 0.71 \\
\hline
\end{tabular}

Levins' measure of niche breadth $\left(B_{i}\right)$ and standarized $B_{i}\left(B_{A}\right)$ calculated with percentage by number $(\% N)$ data. $N$ : total number of prey categories used.

ery. Predators found during this activity, feed mainly on benthic infauna (prey species living in the sediment), epibenthic fauna (prey species living on the surface of the sediment), benthic prey (prey species living on the bottom) or demersal prey (prey species living near the bottom but not linked to it). Therefore, the results of this research are restricted to elasmobranchs that feed on prey species living on the sediment surface or inside the sediment. However, our results contribute significantly to increase the knowledge on the feeding ecology of the other 138 species of fishes coexisting in the same habitat [31], with similar food and space requirements.

Mustelus species have been reported to feed mainly on crustaceans and fish $[18,25,26,32]$, although cephalopods would also be important in their diets [33]. Despite the large number of taxa found in the stomach contents of $M$. lunulatus, one species of stomatopod accounted for most of the prey consumed (stomatopoda $=\% \mathrm{IRI}=96.9$ ). Therefore, M. lunuatus in coastal waters of the Colombian Eastern Tropical Pacific have a specific dietary preference. Besides Ellis et al. [18], this is the only other report of feeding specialization in Mustelus, a genus that has been classified as opportunistic polyphagous [34,35].

The diet of Raja velezi in the neritic zone of the Eastern Pacific Ocean of Colombia showed a low number of prey items in compared with other studies $[20,36,37]$ that found polychaetes, copepods, amphipods, Myscidacea, stomatopods, cephalopods and bivalves. However, the preference of $R$. velezi to feed on decapods and fishes detected in this study was similar to that reported for $R$. naevus [18], $R$. clavata [37], $R$. radiata [38], and $R$. brachyura, $R$. montagui and $R$. eglanteria [39], which also feed upon decapods or fish. Although $R$. velezi is a deep-water ray with a widespread distribution, our results are the first description of the diet of this species in the Tropical Pacific Ocean. Rhinobatos leucorhynchus has been identified as a crustacean predator, with preference for penaeid shrimp $[22,34,40,41]$, although portunid crabs have also been reported as alternative prey [42].

Very little is known of the diet of Dasyatis longa and Zapteryx xyster and this study is the first record on the diet of these species. Similar to other benthic species Dasyatis longa feed on crustacean decapods (stomatopods) and fishes. The preferences for these dietary items have also been reported for Dasyatis americana in the Caribbean Sea [43]. Zapteryx xyster showed the widest feeding spectrum of all elasmobranch studied. This species included stomatopods, decapods and fishes in its diet and, was the most generalist species. Bornatowski et al. [44] reported similar results for $Z$. brevirostris from South Brazil.

Macpherson [45] and Cortés [46] suggested that the relatively big body size of elasmobranch makes it easy for them to expand their feeding spectrum, preying simultaneously on the pelagic and benthic communities. Our study shows that diet breadth was reduced, and prey item distribution by number and weight were similar. Moreover, all studied elasmobranch fed on three main items: Squillidae, Penaeidae and fish. This can be explained by the benthic habits and similarity of sizes and dental structure between $M$. lunulatus and $D$. longa, as well as between Rhinobatos leucorhynchus, Raja velezi and Z. xyster.

The complete dietary overlap detected between M. lunulatus and D. longa, their similar geographical distribution in the study area, and their diurnal activity, suggest that these

Table 5: Niche overlap of elasmobranchs caugth

\begin{tabular}{|c|c|c|c|c|c|}
\hline \multirow[t]{2}{*}{ Species A } & \multicolumn{5}{|l|}{ Species B } \\
\hline & M. lunulatus & D. longa & R. leucorhynchus & R. velezi & Z. xyster \\
\hline M. lunulatus & 1.000 & - & - & - & - \\
\hline D. longa & 0.930 & 1.000 & - & - & - \\
\hline R. leucorhynchus & 0.097 & 0.072 & 1.000 & - & - \\
\hline$R$. velezi & 0.035 & 0.208 & 0.729 & 1.000 & - \\
\hline Z. xyster & 0.343 & 0.515 & 0.603 & 0.935 & 1.000 \\
\hline
\end{tabular}

Niche overlap between five species of elasmobranch caugth in the Eastern Tropical Pacific Ocean of Colombia. Values were calculated using the Pianka measure, indicating the extent to which the diet of Species A overlaps with the diet of Species B. Significant diet overlap ( $>0.6)$. 

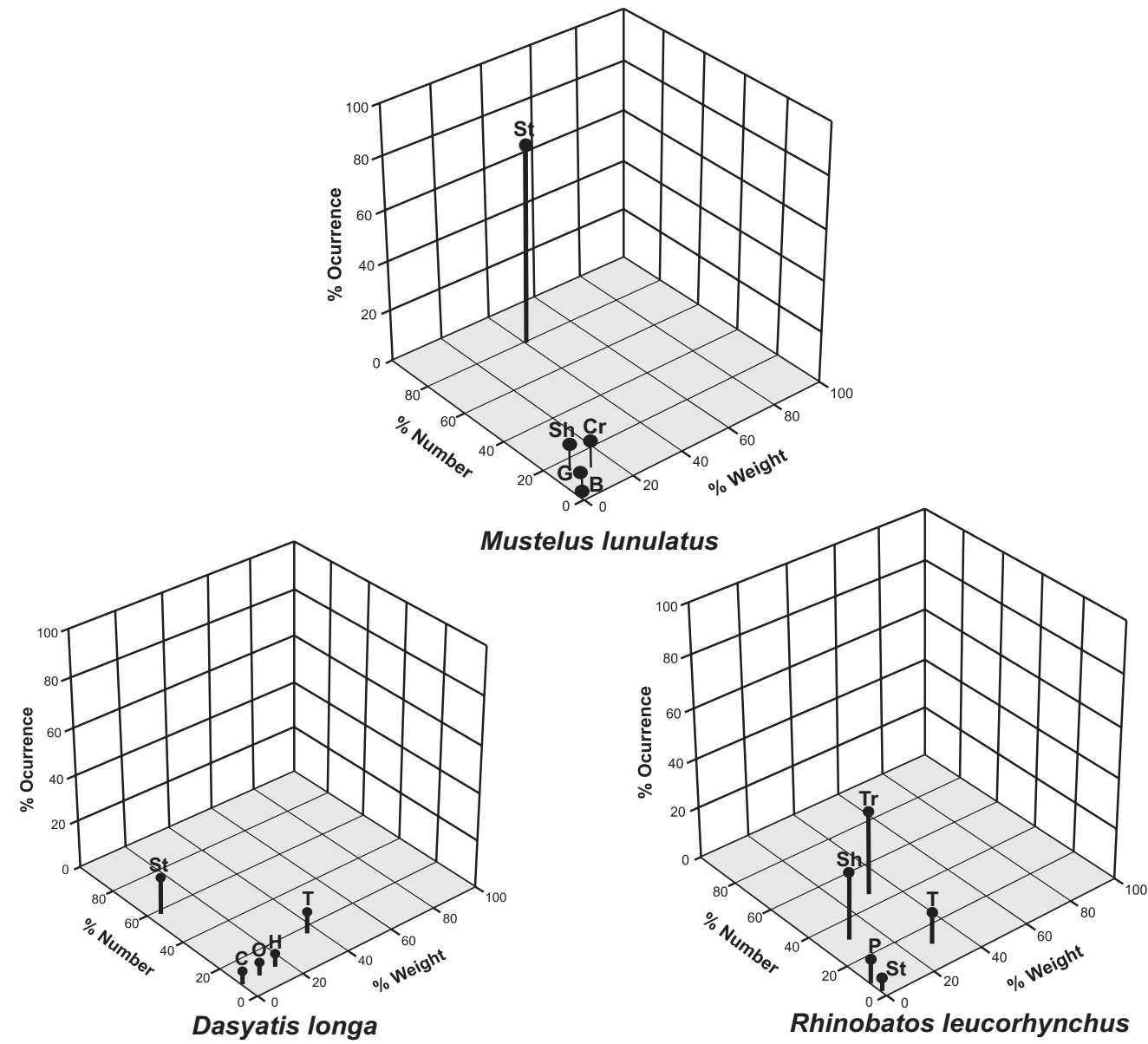

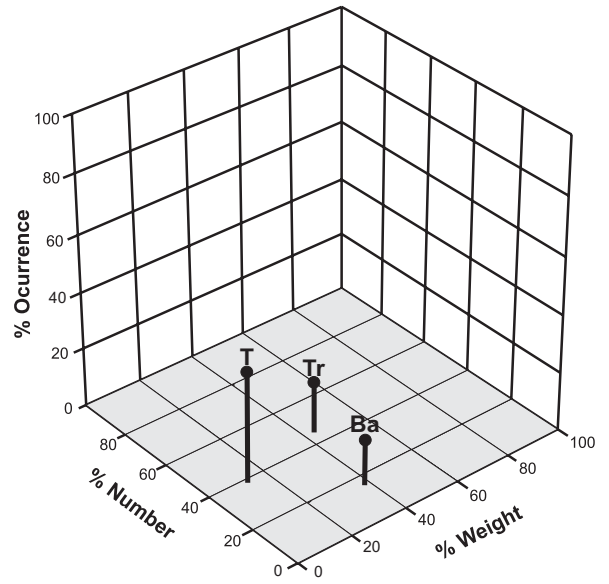

Raja velezi

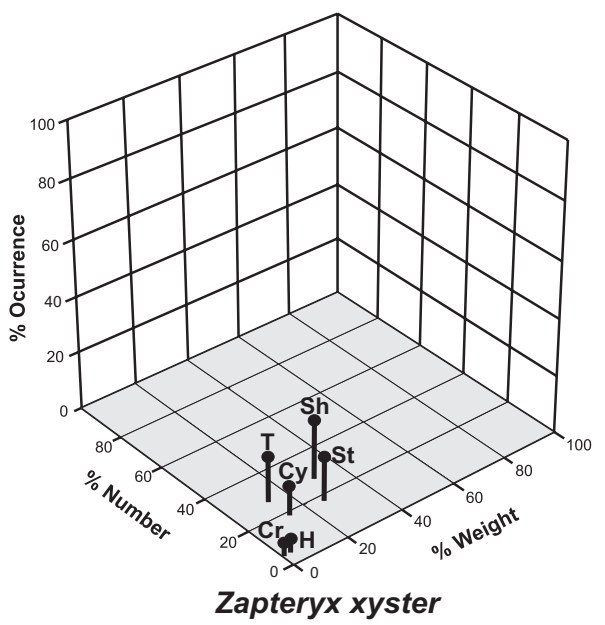

\section{Figure 2}

Three dimensional graphical representation of the relative importance of prey in the diet of five elasmobranch species: percentage by number $(\% \mathbf{N})$, percentage by weight $(\% \mathbf{W})$ and frequency of ocurrence $(\% \mathbf{O})$. Prey items are: St) Stomatopods, Cr) Crabs, Sh) Shrimps, B) Bivalvia, G) Gasteropoda, T) Teleost, O) Olividae, H) Hippidae, C) Cymatidae, Tr) Trachypenaeus, P) Portunidae, Ba) Batrachoididae, Cy) Cynoglossidae. 
species could show a competitive exclusion trend for food resources

[47].

However, the dietary overlap would be reduced when the deep distribution is considered because M. lunulatus occupies deep waters and $D$. longa shallow waters. In contrast the dietary overlap detected between Rhinobatos leucorhynchus, Raja velezi and $Z$. xyster would be significant, since these species have morphological (size and position mouth) and behavioral similarities.

The dietary overlap between Rhinobatos leucorhynchus Raja velezi and R. leucorhynchus - Z. xyster, based on the presence of Trachypenaeus shrimp and fishes, could be compensated by differential diel feeding activity. Rhinobatos leucorhynchus feed mainly during the day whereas $R$. velezi and $Z$ xyster feed manly at night. Furthermore, 89\% of Rhinobatos whose stomachs were analyzed were caught at a deep of 15-30 m, whereas all Raja and Zapteryx specimens were caugth at a depth of $40 \mathrm{~m}$. In contrast, the dietary overlap between $R$. velezi and $Z$. xyster, species with similar feeding activity and bathymetric distribution, suggests that they share only a fraction of their feeding niche, protecting a portion as an uncontested space refuge [47]. In this sense, mantis shrimp would be the feeding refuge of $Z$. xyster. Dietary overlap between $Z$. xyster and R. velezi was fish unidentified and decapods; however this food category was so indeterminate that the evidence of effective dietary overlap is weak. Furthermore, this wide category of prey item overestimate dietary overlap and underestimate niche breadth.

Values of overlap based on simulations suggest that the species studied showed low dietary overlap (mean = 0.44 ). In this study only five species of elasmobranchs were examined. In the study area at least another 12 species of elasmobranchs $[31,48]$ and six species of fishes [31] that share morphological and ecological characteristics with the studied species have been reported. However, all these species and the elasmobranchs that we studied would conform apackaging throughout a feeding axis, and the temporal dynamics of this packaging could be determined by: (i) variety and productivity of available resources, (ii) short-term and long-term environmental variability, and (iii) niche overlap [49,50]. Therefore, if the packaging is modulated by resource availability [50] then the shrimp trawl fishery in the neritic zone of Eastern Pacific of Colombia has severely affected the natural availability of prey for elasmobranch communities [51,52], affecting their structure.

\section{Conclusion}

Shrimps (penaeid and stomatopods) and benthic fishes were the main component of the diet of the elasmobranchs studied. Diet breadth and overlap were relatively low. Determination of food resource partitioning among the batoid species studied was not possible. However, we identified partitions in other niche axes (time of feeding activity and habitat used). It is possible to assume that diffuse competition could be exceeding the biunivocal competition among the studied species. Therefore, this assemblage would have a strong tendency to trophic guild formation.

\section{Methods \\ Study area and sampling}

Stomachs were collected from elasmobranchs caught by bottom trawling with commercial shrimp nets $(2 \mathrm{~m}$ mouth, $50 \mathrm{~mm}$ mesh size), during three cruises in the central fishing area of Eastern Pacific of Colombia (Fig. 3). Twenty four trawls were made over the continental shelf (5-60 $\mathrm{m}$ depth) from the bottom prawn trawler vessel Arraijan from June to November 2001.

The total length of captured elasmobranch was recorded and the stomachs of all specimens were extracted on board, fixed in $10 \%$ formalin, labeled, bagged and transported to the laboratory. Once in the laboratory an incision was made along the longitudinal axis and the stomach contents were emptied into a $1000 \mathrm{ml}$ plastic bucket for rinsing and sorting. Food items were identified to the lowest taxonomic level possible. Numbers and weights (to the nearest $0.1 \mathrm{~g}$ ) of food items were recorded after the items were dried with blotting paper to remove surface moisture.

\section{Numerical analysis}

The quantitative importance of each prey group in the diet of elasmobranch species was estimated by using the frecuency of occurrence $(\% \mathrm{O})$, percentage by number $(\% \mathrm{~N})$ and percentage by weight $(\% \mathrm{~W})$ of prey items in stomachs [28] as:

$$
\% O=\frac{n}{N} \times 100 \quad \% N=\frac{N n}{N p} \times 100 \quad \% W=\frac{P p}{P t} \times 100
$$

where $n=$ number of stomachs that have the prey $i, N=$ total number of analyzed stomachs; $N_{n}=$ number of prey items of prey group n observed, $N_{t}=$ total number of prey items of all prey groups, $P p=$ weight of prey items of prey group $p$ observed and $P t=$ total weight of prey items of all prey groups. The contribution of each prey to the diet was also estimated with the Index of Relative Importance (IRI) and its standardized value (\%IRI) [28] as:

$$
I R I=(\% N+\% W) \times \% O \quad \% I R I=\frac{100 \times I R I i}{\sum I R I i}
$$

where IRIi is the IRI value for each prey category of prey $\mathrm{i}$. 


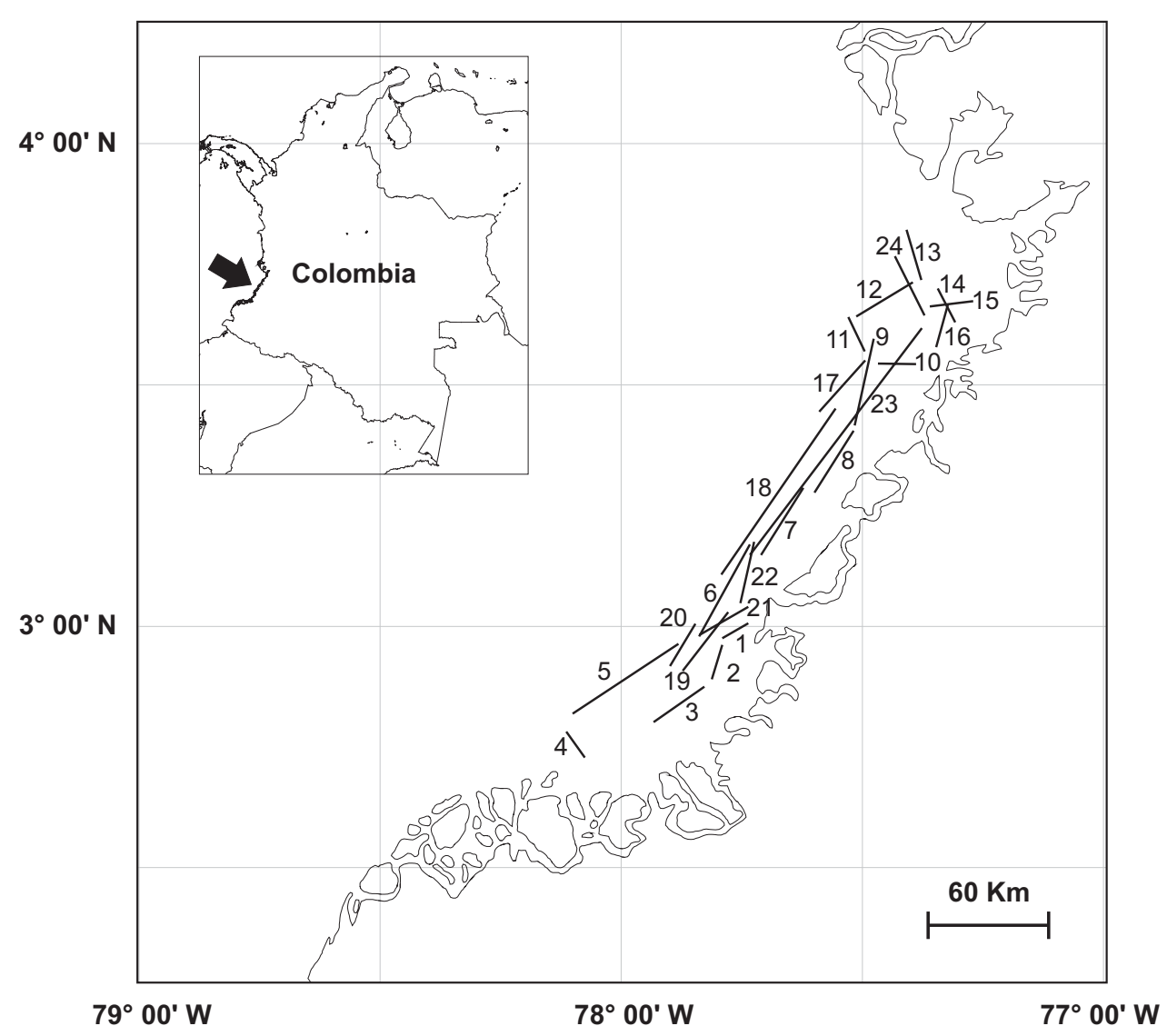

Figure 3

Eastern Pacific Ocean of Colombia (EPOC) showing the central fishing area. Each number represents one trawling episode.

The $\% \mathrm{O}, \% \mathrm{~N}$ and $\% \mathrm{~W}$ values of each prey were plotted following the method proposed by Cortés [28], which allows for an easy and adequate interpretation of prey importance in the diet of predators.

Differences in bathymetric distribution and diel (daynight) feeding activity were analyzed with a Kruskal-Wallis test [53]. For the analysis of feeding activity, the percentage by weight data of each stomach were grouped into four daily activity periods (morning, afternoon, night and dawn).

Diet breadth and overlap were estimated from \%IRI values. Breadth of diet was calculated by using both Levins' index and its standardized form [54] as follows:

$$
B_{i}=\left(\frac{1}{\sum P_{j}^{2}}\right) \quad(\text { iv }) \text { and } B_{A}=\left(\frac{B-1}{n-1}\right)
$$

where $B_{i}=$ Levins' measure of niche breadth, $P_{j}=$ proportion of diet of predator that is made up of prey $j, B_{A}=\mathrm{Lev}-$ ins' standardized niche breadth and $n=$ number of prey categories. Levins' index of niche breadth $\left(B_{i}\right)$ ranges from 1 to $n$, whereas, Levins' standardized niche breadth $\left(B_{A}\right)$ ranges from 0 to 1 ; low values indicate diets dominated by few prey items (specialist predators) while higher values indicate generalist diets [54].

A numerical abundance dietary matrix of prey items was constructed to calculate diet overlap between elasmobranch species by using the Pianka index [54] as follows:

$$
O j k=\frac{\sum_{i}^{n} P_{i j} P_{i k}}{\sqrt{\sum_{i}^{n} p_{i j}^{2} \sum_{i}^{n} p_{i k}^{2}}}
$$

where $\mathrm{O}_{j k}=$ Pianka measure of niche overlap between species $\mathrm{j}$ and species $\mathrm{k}$; and $P_{i j}$ and $P_{i k}=$ proportions of pred- 
ator $j$ and $k$ with prey $i$ in their stomachs. Diet overlap increases as the Pianka index increases and overlap is generally considered to be biologically significant when the value exceeds 0.60 [29].

To evaluate the statistical significance of estimated overlaps, observed overlap values were compared with a distribution of expected values based on simulations of a null model. The distribution of this model was realized with 1000 repetitions using the random algorithm $\mathrm{R} 3$. The observed values were considered statistically different from the null distribution values if they were higher or lower than $95 \%$ of the simulated indices [30].

\section{Authors' contributions}

AFN conceived the study, conducted the in situ work and measurements, analyzed and interpreted the data and wrote the first draft of manuscript. PAM participated in the in situ work, analyzed the data and contributed to the critical review of the draft. AG analyzed the data and contributed to the critical review of the draft. All authors assisted in writing the manuscript and approved the final version.

\section{Acknowledgements}

We thank A. Martinez for providing access to his fishing vessel. E. Rubio and L. Zapata provided invaluable comments on the early version of the work. We also thank Department of Biology, University of Valle and SQUALUS Foundation for supporting the research. IdeaWild granted field equipment. One anonymous reviewer improved the manuscript greatly. We appreciate the improvements in English usage made by E. Cortes.

\section{References}

I. Wheterbee B, Cortés E: Food consumption and feeding habits. In Biology of sharks and their relatives Edited by: Carrier JF, Musik JA, Heithaus M. CRC press. USA; 2004.

2. Krebs C): Ecology. Benjamin Cummings, San Francisco, CA 2001.

3. Root RB: The niche explotation pattern of the blue-gray gnatcatcher. Ecol Mon 1967, 37:317-350.

4. Schoener TW: Trophic structure, reproductive success, and growth rate of fishes in natural and modified head-water stream. Can J Fish Aquat Sci 1974, 39:968-978.

5. Zaret TM, Rand AS: Competition in tropical stream fishes: support for the competitive exclusion principle. Ecology 1971, 52(2):336-342.

6. Hixon MA: Competitive interactions between California reef fishes of the genus Embiotoca. Ecology 1980, 61(4):918-931.

7. Platell ME, Potter IC: Partitioning of food resources among 18 abundant benthic carnivorous fish species in marine waters of the lower west coast of Australia. J Exp Mar Biol Eco 200I, 26I:31-54.

8. Ross ST: Resource partitioning in fish assemblages: a review of field study. Copeia 1986:352-388.

9. Smale MJ: Occurrence and feeding of three shark species, Carcharhinus brachyurus, $C$. obscurus and sphyrna zygaena, on the Eastern Cape coast of South Africa. S Afr J Mar Sci I99I, I I:3 I-42.

10. Vaske-Junior T, Rincón-Filho G: Conteudo estomacal dos tubaroes azul (Prionace glauca) e anequim (Isurus oxyrinchus) en águas oceanicas no sul do Brasil. Rev Brasil Biol 1998, 58(3):445-452.

II. Carrasón M, Stefanescu C, Cartes JE: Diets and bathymetric distributions of two bathyal sharks of the Catalan deep sea (Western Mediterranean). Mar Ecol Prog Ser 1992, 82:2I-30.
12. Cortés $\mathrm{E}$, Gruber $\mathrm{SH}$ : Diet, feeding habits, and estimates of daily ration of young lemon shark, Negaprion brevirostris (Poey). Copeia 1990:204-218.

13. Simpfendorfer CA: Diet of the Australian Sharpnose shark Rhizoprionodon taylori, from northern Queensland. Mar Fresh Res 1992, 49:757-76I.

14. Wetherbee BM, Lowe CG, Crowe GL: Biology of the Galapagos shark, Carcharhinus galapagensis, in Hawaii. Environ Biol Fish 1996, 45:299-310.

15. Heithaus MR: The biology of tiger sharks, Galeocerdo cuvier, in Shark Bay, Western Australia: sex ratio, size distribution, diet, and seasonal changes in catch rates. Environ Biol Fish 200I, 6I:25-36.

16. Bethea D, Carlson JK, Buckel JA, Satterwhite M: Ontogenetic and site-related trends in the diet of the atlantic sharpnose shark Rhizoprionodon terraenovae from the northeast gulf of Mexico. Bull Mar Sci 2006, 78(2):287-307.

17. Brickle P, Laptikhovsky V, Pompert J, Bishop A: Ontogenetic changes in the feeding habits and dietary overlap between three abundant rajoids species on the Falkland Island's shelf. J Mar Biol Ass UK 2003, 83: I I I 9-I I 25.

18. Ellis JR, Pawson MG, Shackley SE: The comparative feeding ecology of six species of shark and four species of ray (Elasmobranchii) in the North-East Atlantic. J Mar Biol Ass UK 1996, 76:89-106.

19. Bethea D, Buckel JA, Carlson JK: Foraging ecology of the early life stages of four sympatric shark species. Mar Ecol Prog Ser 2004, 268:245-264.

20. Orlov AM: The diet and feeding habits of some Deep-Water benthic skates (Rajidae) in the pacific waters off the Northern Kuril islands southeastern Kamchatka. Alas Fish Res Bull 1998, 5(I): I-17.

21. Platell ME, Potter IC, Clarke KR: Resource partitioning by four species of elasmobranch (Batoidea:Urolophidae) in costal waters of temperate Australia. Mar Biol 1998, 131:719-734.

22. White WT, Platell ME, Potter IC: Comparison between the diets of four abundant species of elasmobranch in a subtropical embayment: implications for resource partitioning. Mar Biol 2004, 1 44:439-448.

23. Papastamatiou YP, Wetherbee BM, Lowe CG, Crow GL: Distribution and diet of four species of carcharhinid shark in the Hawaiian Islands: evidence for resource partitioning and competitive exclusion. Mar Ecol Prog Ser 2006, 320:239-25I.

24. Mejía-Falla PA, Navia AF, Giraldo A: Notas biológicas de la raya ocelada (Zapteryx xyster) en la zona central de pesca del Pacífico colombiano. Invest Mar 2006, 34(2): $18 \mid-185$.

25. Navia AF, Giraldo A, Mejía-Falla PA: Notas sobre la biología y dieta del toyo vieja (Mustelus lunulatus) de la zona central de pesca del Pacífico colombiano. Invest Mar 2006, 34(2):217-222.

26. Gómez G, Zapata LA, Franke R, Ramos GE: Hábitos alimentarios de Mustelus lunulatus y $M$. henlei (Pises: Triakidae) colectados en el Parque Nacional Natural Gorgona, Pacífico colombiano. Bol Inv Mar Cost 2003, 32:219-231.

27. Mejía-Falla PA, Navia AF, Mejia-Ladino LM, Acero A, Rubio E: Tiburones y rayas de Colombia (Pisces: Elasmobranchii). Lista revisada, actualizada y comentada. Bol Inv Mar Cost 2007 in press.

28. Cortés $E$ : A critical review of methods of studying fish feeding base on analysis of stomach contents: application to elasmobranch fishes. Can J Fish Aquat Sci 1997, 54:726-738.

29. Zares TM, Rand AS: Competition in tropical stream fishes: support for the competitive exclusion principle. Ecology 1971, 52:336-342.

30. Gotelli NJ, Graves GR: Null Models in ecology. Smithsonian Institution Press. Washington. DC; 1996.

31. Navia AF, Mejía-Falla PA: Aspectos biológicos, ecológicos y pesqueros de la fauna capturada incidentalmente en la pesca de camarón de aguas someras en el Pacífico colombiano: informe final y propuesta metodológica para monitoreos a bordo de embarcaciones arrastreas. Doc tec No FSO206 2006:42p.

32. Rojas JR: Reproducción y alimentación del tiburón enano Mustelus dorsalis (Pises: Triakidae) en el Golfo de Nicoya, Costa Rica: Elementos para un manejo sostenible. Rev Biol Trop 2006, 54(3):86I-87I. 
33. Capapé C: Observations sur le régime alimentaire de 29 Selaciens pleurotêrmes des côtes tunisiennes. Arch Inst Pasteur Tunis 1975, 52:395-4I4.

34. Talent L: Food habits of the gray smoothhound Mustelus californicus, the Brown-smoothhound, Mustelus henlei, the shovelnose guitarfish Rhinobatos productos and the bat ray Myliobatis californica in Elkhorn slough, California. Cal Fish Game 1982, 68:224-234.

35. Chiaramonte G, Pettovello P: The biology of Mustelus schmitti in southern Patagonia, Argentina. J Fish Biol 2000, 57:930-942.

36. Galvan-Magaña F, Nienhuis HJ, Klimley AP: Seasonal abundance and feeding habits of sharks of the lower gulf of California, México. Calif Fish and Game 1989, 75(2):74-84.

37. Morato T, Solá E, Grós MP, Menezes G: Diets of thornyback ray (Raja clavata) and tope shark (Galeorhinus galeus) in the bottom longline fishery of the Azores, northeastern Atlantic. Fish Bull 2003, 1 01:590-602.

38. Pedersen SA: Feeding habits of starry ray (Raja radiata) in West Greenlad waters. ICES J Mar Sci 1995, 52:43-53.

39. Schwartz FJ: Biology of the clearnose skate Raja eglanteria from North Carolina. Florida Scientist 1996, 59(2):82-95.

40. Ismen A, Yigin C, Ismen P: Age, growth, reproductive biology and feed of the common guitarfish (Rhinobatos rhinobatos Linnaeus, 1758) in Iskenderun Bay, the eastern Mediterranean sea. Fish Res 2007, 84(2):263-269.

41. Shibuya A, Rosa RS, Soares MC: Note on the diet of the guitarfish Rhinobatos percellens (Walbaum, 1792) (Elasmobranchii: Rhinobatidae) from the coast of Paraíba, Brazil. Acta Biologica Leopoldensia 2005, 27(I):63-34.

42. Capapé C, Zaouali J: Diet of two selachians common to the Gulf of Gabes (Tunisia): Rhinobatos rhinobatos (Linnè, I758) and Rhinobatos cemiculus (Geoffroy Sainte-Hilarie, I8I7). Arch Inst Pasteur Tunis 1979, 56(3):285-306.

43. Stokes MD, Holland ND: Southern Stingray (Dasyatis americana) feeding on lancelets (Branchiostoma floridae). J Fish Biol 1992, 41: 1043-1044.

44. Bornatowski $\mathrm{H}$, Abilhoa $\mathrm{V}$, Freitas $\mathrm{MO}$ : Alimentacao da raia-viola Zapteryx brevirostris na baía de ubatuba-enseada, Sao franciso do sul, Santa Catarina, Brasil. Estud Biol 2005, 27(6I):3I-36.

45. Macpherson E: Resource partitioning in a Mediterranean demersal fish community. Mar Ecol Progr Ser 1981, 4:183-193.

46. Cortés E: Standardized diet compositions and trophic levels of sharks. ICES J Mar Sci 1999, 56:707-7I7.

47. Pianka ER: Evolutionary Ecology 6th edition. Addison Wesley; 2000.

48. Navia AF: Aspectos de la biología de los elasmobranquios capturados como fauna acompañante del camarón en aguas someras del Pacífico colombiano. B.Sc. Thesis, Universidad del Valle, Cali, Colombia 2002.

49. MacArthur RH: Species packing and competitive equilibrium among many species. Theo Pop Biol 1970, I: I-I I.

50. May RM, MacArthur RH: Niche overlap as a function of environmental variability. Proc Nat Acad Sci 1972, 69: I I09-I I I3.

5I. Invemar: Informe del estado de los ambientes marinos y costeros en Colombia: 2000. Serie documentos generales No. 3, Santa Marta, Colombia 200I.

52. Zapata LA, Rodríguez G, Beltrán B: Prospección de los principales bancos de pesca en el Pacífico colombiano, durante noviembre de 1998. Boletín científico INPA 1999, 6: I I I-I75.

53. Zar J: Biostatistical Análisis 4th edition. Pearson education. India; 1999.

54. Krebs CJ: Ecological methodology 2nd edition. Benjamin Cummings press, Menlo Park, California; 1999.

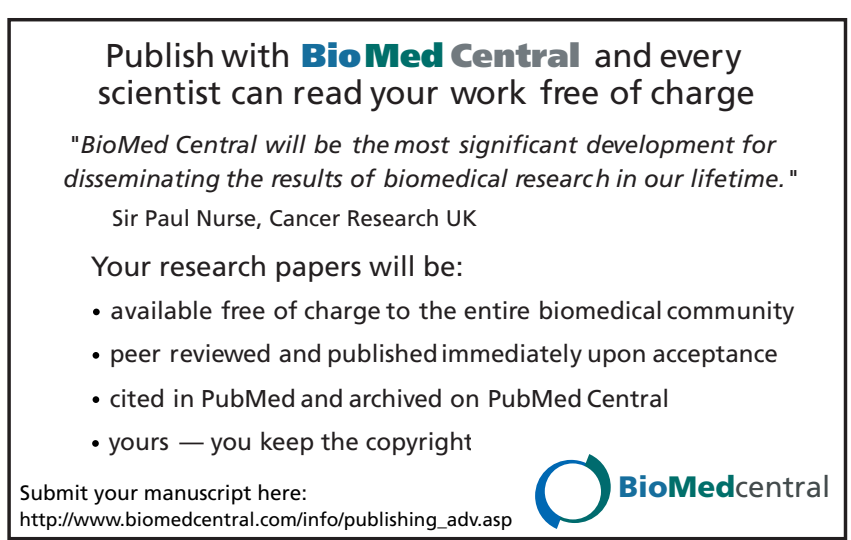

